\title{
Association and Path Analysis in Advance Pakistani Bread Wheat Genotypes
}

\author{
Abdul Wahid Baloch ${ }^{1}$, Munaiza Baloch* ${ }^{1}$, Irfan Ahmed Baloch ${ }^{1}$, Shah \\ Nawaz Mari ${ }^{1}$, Dalel Khan Mandan ${ }^{2}$ and Shafiq Ahmed Abro ${ }^{3}$ \\ ${ }^{1}$ Department of Plant Breeding \& Genetics, Sindh Agriculture University, Tandojam, ${ }^{2}$ Southern Wheat Research \\ Station, Tandojam, ${ }^{3}$ Nuclear Institute of Agriculture, Tandojam, Pakistan \\ *Corresponding author's email: munaizabaloch@yahoo.com
}

\section{Citation}

Abdul Wahid Baloch, Munaiza Baloch, Irfan Ahmed Baloch, Shah Nawaz Mari, Dalel Khan Mandan and Shafiq Ahmed Abro. Association and Path Analysis in Advance Pakistani Bread Wheat Genotypes. Pure and Applied Biology. Vol. 3, Issue 3, 2014, pp 115-120

\begin{abstract}
An investigation was carried out on correlation and path analysis for seven characters on eight advance bread wheat cultivars which were grown in randomized complete block design with four replications during rabi, 2012-13 at Southern Wheat Research Station, Tandojam, Pakistan. All the growth and yield components including plant height, spike length, spikelets spike ${ }^{-1}$, grains spike ${ }^{-1}$, grain yield plant $^{-1}$ and seed index (1000-grain weight) were significantly $(\mathrm{P}<0.01)$ different among the wheat genotypes except tillers plant ${ }^{-1}$. Among the genotypes, Abadgar resulted in maximum plant height $(116.65 \mathrm{~cm})$; while TD-1 surpassed all other tested genotypes for tillers plant ${ }^{-1}$ (13.550), spike length $(13.488 \mathrm{~cm})$, grain spike ${ }^{-1}(71.870)$, seed index $(54.362 \mathrm{~g})$ and grain yield plant ${ }^{-1}(18.900 \mathrm{~g})$. Significant $(\mathrm{P}<0.05)$ and positive correlations among various traits were recorded. Tillers plant ${ }^{-1}$ showed positive and significant correlation with grains spike ${ }^{-1}\left(0.725^{*}\right)$, seed index $\left(0.742^{*}\right)$ and grain yield plant ${ }^{-1}\left(0.814^{*}\right)$ while the trait spike length established positive and significant association with spikelets spike ${ }^{-1}\left(0.844^{* *}\right)$, grains spike ${ }^{-1}$ $\left(0.838^{*}\right)$ seed index $\left(0.804^{*}\right)$ and grain yield plant ${ }^{-1}\left(0.881^{* *}\right)$. The character spikelets spike ${ }^{-1}$ also showed significant and positive associations with various traits including grain spike ${ }^{-1}\left(0.841^{*}\right)$, seed index $\left(0.783^{*}\right)$ and grain yield plant $^{-1}\left(0.804^{*}\right)$. Similarly, grains spike ${ }^{-1}$ and seed index developed positive and significant $\left(0.984^{* *}\right)$ correlations between them and also both traits made their significant and positive association with grain yield plant ${ }^{-1}$ with correlation values of $0.969^{* *}$ and $0.940^{* *}$, respectively. Overall, an intensive selection for tillers plant ${ }^{-1}$, spike length, spikelets spike ${ }^{-1}$, seed index and grain yield plant ${ }^{-1}$ will ultimately improve seed yield in wheat. Since, these six traits are correlated among themselves; selection in one or more traits will result in the improvement of the other traits. Path coefficient analysis indicated that the maximum direct positive effect on grain yield plant ${ }^{-1}$ was contributed by grains spike ${ }^{-1}(0.8416)$ and seed index $(0.5481)$. So, direct selection of genotypes for grain yield through grains spike $^{-1}$ and seed index could be effective.
\end{abstract}

Keywords: Bread wheat, Correlation, Grain yield, Path analysis, Pakistan

\section{Introduction}

Wheat (Triticum aestivum L.) is used as a staple food of the major civilizations since old times. It grows most extensively crop among cereals crop in the world, engaging $17 \%$ of crop acreage world over, giving food about $40 \%$ of world population and supplying $20 \%$ of the total food calories and protein in human diet [1]. In Pakistan, the production of 24.231 million tons was achieved during 2012-13 showing 3.20 percent increase over the preceding year; whereas the yield was $2787 \mathrm{~kg} \mathrm{ha}^{-1}$, showing 2.7 percent increase over the last years yield $\mathrm{ha}^{-1}$. Thus, indicating a positive trend in the area, grain production and yield per hectare, and this was mainly associated with the timely sowing of wheat and favorable climatic factors [2]. Wheat grain yield varies widely as a consequence of its interaction with a variety of environmental factors since it is a complex quantitative genetic parameter and is the result of numerous contributing factors affecting 
grain yield directly or indirectly. Wheat grain production can be improved through the development of productive varieties which better adjust in diverse agro-climatic conditions and also resist all types of biotic and abiotic stresses. Selection and improvement in respect to grain yield can only be efficient if adequate genetic variability is exit in the breeding materials [3].

Correlation coefficient is an important statistical technique which can assist wheat breeders in selection crop plants for higher yields. Some of the research workers reported the positive correlation between grain yield and its components in wheat crop such as grains number spike ${ }^{-1}$ [4], spikes number plant $^{-1}$ [5] straw yield [6], harvest index [7] and biological yield [8]. Since the correlation coefficients commonly explain relationships among independent variables and the degree of linear relations among the variables, however, they could not adequately describe the relationship when a clear cause-result relationship was established between the variables [9]. Thus, the direct and indirect effects between yield and its components should be identified in breeding programs [10]. Partitioning the correlation coefficient into direct and indirect effects can be done through path analysis technique [11]. Path coefficients have been used to develop selection criteria for complex traits in several crop species of economic importance such as wheat $[12,13]$, rice [14], maize [15] and cotton [16]. Therefore, the current investigation was undertaken to find out the correlation and path coefficient of wheat genotypes and identify the promising sources for further breeding programs.

\section{Materials and methods}

The present study was conducted during rabi season, 2012-13 at Southern Wheat Research Station, Tando jam. The experiment was aimed to compute coefficients of correlation and path analysis for yield and its associated traits of bread wheat genotypes. The experimental material was sown in Randomized
Complete Block Design with four replications. The trial consisted of four rows of $320 \mathrm{~cm}$ length and 210 $\mathrm{cm}$ width for each genotype per replication. The sowing was done by dibbling, keeping $20 \mathrm{~cm}$ space between plants and $30 \mathrm{~cm}$ between rows. The experimental site is situated at latitude $25^{\circ} 25^{\prime} 28^{\prime \prime} \mathrm{N}$, and longitude $68^{\circ} 32^{\prime} 25^{\prime \prime} \mathrm{E}$ and is at an elevation of about $26 \mathrm{~m}$ above the mean sea level. The soil type was clay loam with $\mathrm{pH}$ 7.5. The recommended dose of fertilizer (134N: $67 \mathrm{P}_{2} \mathrm{O}_{5} \mathrm{~kg} / \mathrm{ha}$ ) was applied to the experiment. The $\mathrm{N}$ fertilizer was used in three splits whereas $\mathrm{P}$ fertilizer was applied before the cultivation. The experiment was irrigated six times during entire cropping season, such as; first irrigation was applied at crown stage, second at tillering stage, third at booting stage, fourth at flowering stage, fifth at milky stage, and sixth at dough stage. The weedicide Loughran (160 grams/acre) was used to remove weeds from the experiment. Ten plants were randomly selected and tagged from each replication. After collecting necessary data under field conditions, other observations were recorded in laboratory. Eight advance cultivars bread wheat were used in the present study such as TJ-83, Sarsabz, TD1, Abadgar, Mehran-89, Anmol, Khirman and Sogat. The traits were studied plant height $(\mathrm{cm})$, tillers plant ${ }^{-}$ ${ }^{1}$, spike length $(\mathrm{cm})$, spikelets spike ${ }^{-1}$, grains spike ${ }^{-1}$, seed index (1000 grain weight, g) and grain yield plant $^{-1}(\mathrm{~g})$. Correlation coefficients and path analysis were worked out by using R and SPSS v.17 statistical computer softwares, respectively.

\section{Results and discussion}

The amount of genetic variability in base population and relationship of different characters towards grains yield is the key of any breeding efforts. In this study, the analysis of variation revealed highly significant differences among the cultivars for all the studied traits except number of tillers plant ${ }^{-1}$, indicating the availability of substantial genetic diversity in the studied experimental materials which can rather be exploited in future breeding programs.

Table 1. Mean squares from analysis of variances for various traits in wheat cultivars

\begin{tabular}{|c|c|c|c|}
\hline \multirow[b]{2}{*}{ Traits } & \multicolumn{3}{|c|}{ Mean squares } \\
\hline & $\begin{array}{c}\text { Replication } \\
\text { D.F. }=03\end{array}$ & $\begin{array}{c}\text { Varieties } \\
\text { D.F.=7 }\end{array}$ & $\begin{array}{c}\text { Error } \\
\text { D.F.=21 }\end{array}$ \\
\hline Plant height & 4.75 & $1075.77 * *$ & 2.59 \\
\hline Tillers plant ${ }^{-1}$ & 29.10 & $5.93^{\mathrm{NS}}$ & 2.94 \\
\hline Spike length & 10.92 & $3.91^{* *}$ & 0.75 \\
\hline Spikeltes spike $^{-1}$ & 6.29 & $18.14 * *$ & 3.03 \\
\hline Grains spike ${ }^{-1}$ & 2.64 & $113.23^{* *}$ & 2.61 \\
\hline Seed index & 6.66 & $91.37 * *$ & 2.32 \\
\hline Grain yield plant $^{-1}$ & 0.59 & $14.14 * *$ & 0.40 \\
\hline
\end{tabular}

$* *=$ Significant at 0.01 probability level; NS= Non-significant 
The data with regards to mean performance of wheat genotypes for different agronomic traits are given in Table 2. The data show that variety Abadgar produced plants of significantly $(\mathrm{P}<0.01)$ maximum height $(116.65 \mathrm{~cm})$, followed by varieties Mehran-89 and Sarsabz with mean plant height of 112.72 and $94.80 \mathrm{~cm}$, respectively; while variety TD-1 recorded the minimum plant height of $64.64 \mathrm{~cm}$. The number of tillers plant ${ }^{-1}$ was maximum (13.55) in dwarf wheat variety TD-1, followed by varieties Abadgar and Anmol with 11.87, and 11.70 tillers plant ${ }^{-1}$, respectively; while the minimum number of tillers (9.35) plant $^{-1}$ was resulted by variety Khirman. The average spike length was maximum $(13.48 \mathrm{~cm})$ in case of variety TD-1, followed by varieties Mehran89 (13.47) and TJ-83 (12.64) and minimum spike length $(10.40 \mathrm{~cm})$ was noted in variety Soghat. In case of spikelets spike ${ }^{-1}$, the trait was significantly $(\mathrm{P}<0.01)$ maximum (22.82) in the variety Mehran-89, followed by varieties TD-1 (22.20) and Sarsabz (22.10) where as the variety Anmol (17.35) showed minimum spikelets spike ${ }^{-1}$. The mean number of grains spike $^{-1}$ was significantly $(\mathrm{P}<0.01)$ higher (71.87) in case of variety TD-1, followed by varieties Sarsabz (66.75) and Mehran-89 (65.87) grains spike ${ }^{-1}$. The data in relation to mean agronomic performance of grain yield plant $^{-1}$ and seed index (Table-2) indicate that wheat variety TD-1 displayed significantly $(\mathrm{P}<0.01)$ maximum grain yield $(18.90 \mathrm{~g})$ plant $^{-1}$, followed by varieties Sarsabz and Mehran with 16.15 and 16.13 g mean grain yield plant $^{-1}$, respectively; while the minimum grain yield plant $^{-1}$ $(12.43 \mathrm{~g})$ was noted in variety Soghat. The seed index (1000 grains weight $\mathrm{g})$ was significantly $(\mathrm{P}<0.01)$ higher $(54.36 \mathrm{~g})$ in variety TD-1, followed by mean seed index value of 50.96 and $48.56 \mathrm{~g}$ observed in varieties Sarsabz and Mehran-89, respectively; whereas the lowest seed index (39.00 g) was obtained in variety Soghat. All in all, TD-1 surpassed all other tested genotypes for tillers plant ${ }^{-1}$, spike length, spikelets spike ${ }^{-1}$, grain spike ${ }^{-1}$, seed index and grain yield plant $^{-1}$, suggesting that this cultivar can further be utilized in different breeding programs to develop improved bread genotypes for variety of characters.

Table 2. Mean performance of wheat cultivars for various traits.

\begin{tabular}{|c|c|c|c|c|c|c|c|}
\hline Genotypes/traits & $\begin{array}{l}\text { Plant height } \\
\text { (cm) }\end{array}$ & Tillers plant $^{-1}$ & $\begin{array}{l}\text { Spike length } \\
(\mathrm{cm})\end{array}$ & $\begin{array}{l}\text { Spikelets } \\
\text { spike }^{-1}\end{array}$ & $\begin{array}{l}\text { Grains } \\
\text { spike }^{-1}\end{array}$ & $\begin{array}{l}\text { Seed index } \\
\text { (g) }\end{array}$ & $\begin{array}{l}\text { Grain yield } \\
\text { plant }^{-1}\end{array}$ \\
\hline & $84.05 \mathrm{f}$ & $11.52 \mathrm{abc}$ & $12.64 \mathrm{ab}$ & $19.57 \mathrm{bc}$ & $59.50 \mathrm{~d}$ & $43.36 \mathrm{e}$ & $15.11 \mathrm{~cd}$ \\
\hline 3 & $94.80 \mathrm{c}$ & $10.55 \mathrm{bc}$ & $12.63 \mathrm{ab}$ & $22.10 \mathrm{ab}$ & $66.75 \mathrm{~b}$ & $50.96 \mathrm{~b}$ & $16.15 \mathrm{~b}$ \\
\hline Sarsbaz & $6464 \mathrm{~g}$ & & & & 7187 & 5436 & 1800 \\
\hline TD-1 & & & & & & $J 4 . J 0 \mathrm{a}$ & $10.70 \mathrm{a}$ \\
\hline Abadgar & $116.65 \mathrm{a}$ & $11.87 \mathrm{ab}$ & $12.15 \mathrm{~b}$ & $21.27 \mathrm{ab}$ & $63.87 \mathrm{c}$ & $48.17 \mathrm{c}$ & $15.53 \mathrm{bc}$ \\
\hline Mehran-89 & $112.72 b$ & $11.05 \mathrm{abc}$ & $13.47 \mathrm{a}$ & $22.82 \mathrm{a}$ & $65.87 \mathrm{bc}$ & $48.56 \mathrm{c}$ & $16.11 \mathrm{~b}$ \\
\hline Anmol & $86.78 \mathrm{e}$ & $11.70 \mathrm{abc}$ & $11.82 \mathrm{~b}$ & $17.40 \mathrm{c}$ & $59.75 \mathrm{~d}$ & $45.68 \mathrm{~d}$ & $14.07 \mathrm{e}$ \\
\hline Khirman & $90.70 \mathrm{~d}$ & $9.35 \mathrm{bc}$ & $12.25 \mathrm{ab}$ & $20.45 \mathrm{ab}$ & $59.87 \mathrm{~d}$ & $44.25 \mathrm{de}$ & $14.50 \mathrm{de}$ \\
\hline Soghat & $94.58 \mathrm{c}$ & $10.70 \mathrm{c}$ & $10.40 \mathrm{c}$ & $17.35 \mathrm{c}$ & $55.00 \mathrm{e}$ & $39.00 \mathrm{f}$ & $12.43 \mathrm{f}$ \\
\hline LSD $(p \leq 0.05)$ & 2.365 & 2.524 & 1.281 & 2.560 & 2.375 & 2.242 & 0.938 \\
\hline
\end{tabular}


Grain yield is the end product of interactions of many factors known as contributing components since it is complex character. Understanding of the interaction of characters among themselves and with the environment clues has been of great use in the plant breeding; correlation between different characters of plant could arise because of linkage, pleiotrophy or developmentally influenced functional relationships. Correlation studies offer information on the nature and extent of association between any two pairs of metric characters. From this it could be possible to bring about genetic up-gradation in one character by selection of the other pair. The present study showed significant $(\mathrm{P}<0.05)$ and positive correlation among various traits such as number of tillers plant ${ }^{-1}$ made positive and significant with grains $\operatorname{spike}^{-1}\left(0.725^{*}\right)$, seed index $\left(0.742^{*}\right)$ and grain yield plant ${ }^{-1}\left(0.814^{*}\right)$. The traits spike length also established positive and significant association with spikelets spike $^{-1}$ $\left(0.844^{* *}\right)$, grains $\operatorname{spike}^{-1}\left(0.838^{*}\right)$ seed index $\left(0.804^{*}\right)$ and grain yield plant ${ }^{-1}\left(0.881^{* *}\right)$. The character spikelets spike $^{-1}$ showed significant and positive associations with various traits including grain spike ${ }^{-1}$ $\left(0.841^{*}\right)$, seed index $\left(0.783^{*}\right)$ and grain yield plant ${ }^{-1}$ $(0.804 *)$. Similarly, the traits grain spike ${ }^{-1}$ and seed index developed positive and significant correlation $\left(0.984^{* *}\right)$ between them and also both traits made their significant and positive association with grain yield plant ${ }^{-1}$ with correlation values of $0.969 * *$ and $0.940^{* *}$, respectively. Overall, an intensive selection for number of tillers plant ${ }^{-1}$, spike length, spikelets spike $^{-1}$, seed index and grain yield per plant will ultimately improve seed yield in wheat. Since these six traits are correlated among themselves, selection in one of the traits will implicitly result in the improvement of the other traits. Negative and nonsignificant correlations of plant height were found with number of tillers plant ${ }^{-1}\left(-0.446^{\mathrm{NS}}\right)$, spike length $\left(-0.131^{\mathrm{NS}}\right)$, grains spike ${ }^{-1}\left(-0.199^{\mathrm{NS}}\right)$ seed index ($\left.0.199^{\mathrm{NS}}\right)$ and grain yield plant ${ }^{-1}\left(-0.340^{\mathrm{NS}}\right)$ (Table 3$)$.

The plant height showed negative association with these yield contributing components thus indicating that more preference should be given to dwarf varieties as they could withstand lodging and hence these could be used to the advantage in direct selection for grain yield. These results are in agreement with those of Hussain [4], Hannachi [5] and Fellahi [6].

The path coefficient analyses emerged to give a clue to the contribution of various components of yield to over all grain yields in the genotypes under study. It provides an efficient way of finding out direct and indirect effects of different traits on grain yield. The yield components such as plant height, number of tillers plant ${ }^{-1}$, spike length, grains number spike ${ }^{-1}$, spikelets spike ${ }^{-1}$ and seed index (1000 grain weight) were considered as independent variables and path analysis was applied in order to determine the effect and contribution ratios of these components on grain yield plant ${ }^{-1}$ which is dependent variable (Table 4). Path coefficient analysis for grain yield plant ${ }^{-1}$ showed that traits like grains spike ${ }^{-1}(0.8416)$ and seed index (0.5481) showed highest positive direct effect towards seed yield. The high positive direct effect of grain spike ${ }^{-1}$ and seed index was responsible for its significant positive association with seed yield plant $^{-1}$. This means that a slight increase in one of the above traits may directly contribute to seed yield. Similar results were reported by Shahryari [8] and Meyari [17]. The high positive indirect contribution towards grain yield plant $^{-1}$ was exhibited by plant height via number of tillers plant ${ }^{-1}(0.2964)$; number of tillers plant ${ }^{-1}$ via grains spike ${ }^{-1}(0.8264)$ and seed index (0.5570); spike length via grains spike $^{-1}$ (0.7735) and seed index (0.4906); spikelets spike ${ }^{-1}$ via grains $\operatorname{spike}^{-1}(0.7999)$ and seed index (0.4711); grains spike ${ }^{-1}$ via seed index $(0.5481)$ and seed index via grain spike ${ }^{-1}(0.8416)$. Similar results reported by Mollasadeghi [18] who studied the cause and effect relations among some traits of wheat genotypes and path analysis and results showed that the grain spike ${ }^{-1}$ and seed index had a direct and positive effect over.

Table 3. Correlation (r) coefficients among various traits in wheat cultivars

\begin{tabular}{|c|c|c|c|c|c|c|c|}
\hline characters & $\begin{array}{c}\text { Plant } \\
\text { height }\end{array}$ & Tillers plant $^{-1}$ & Spike length & $\begin{array}{c}\text { Spikelets } \\
\text { spike }^{-1}\end{array}$ & Grains spike $^{-1}$ & Seed index & Grain yield plant $^{-1}$ \\
\hline Plant height & 1 & $-0.446^{\mathrm{NS}}$ & $-0.131^{\mathrm{NS}}$ & $0.170^{\mathrm{NS}}$ & $-0.199^{\mathrm{NS}}$ & $-0.199^{\mathrm{NS}}$ & $-0.340^{\mathrm{NS}}$ \\
\hline Tillers plant ${ }^{-1}$ & & 1 & $0.676^{\mathrm{NS}}$ & $0.405^{\mathrm{NS}}$ & $0.725^{*}$ & $0.742^{*}$ & $0.814^{*}$ \\
\hline Spike length & & & 1 & $0.844^{* *}$ & $0.838^{* *}$ & $0.804^{*}$ & $0.881^{* *}$ \\
\hline Spikelets spike ${ }^{-1}$ & & & & 1 & $0.841^{* *}$ & $0.783^{*}$ & $0.804^{*}$ \\
\hline Grains spike ${ }^{-1}$ & & & & & 1 & $0.984^{* *}$ & $0.969^{* *}$ \\
\hline Seed index & & & & & & 1 & $0.940^{* *}$ \\
\hline Grain yield plant ${ }^{-1}$ & & & & & & & 1 \\
\hline
\end{tabular}

$*=$ significant at 0.05 probability level; $* *=$ Significant at 0.01 probability level; NS= Non-significant 
Pure Appl. Bio., 3(3): 115-120, September- 2014

Table 4. Path coefficient analysis of various traits in bread wheat genotypes

\begin{tabular}{|c|c|c|c|c|c|c|}
\hline Characters & Plant height & Tillers plant ${ }^{-1}$ & Spike length & Spikelets spike $e^{-1}$ & Grains spike ${ }^{-1}$ & Seed index \\
\hline Plant height & -0.3858 & 0.2964 & 0.0143 & 0.0128 & -0.1693 & -0.1089 \\
\hline Tillers plant $^{-1}$ & 0.2356 & -0.4853 & -0.0624 & 0.0367 & 0.8264 & 0.5570 \\
\hline Spike length & 0.0602 & -0.3301 & -0.0917 & 0.0622 & 0.7735 & 0.4906 \\
\hline Spikelets spike ${ }^{-1}$ & 0.3702 & -0.2665 & -0.0853 & 0.0668 & 0.7999 & 0.4711 \\
\hline Grain spike $^{-1}$ & 0.0776 & -0.4766 & 0.4302 & 0.0635 & 0.8416 & 0.5481 \\
\hline Seed index & 0.0766 & -0.4933 & -0.0821 & 0.0575 & 0.8416 & 0.5481 \\
\hline
\end{tabular}

Josm [19] estimated correlation and path coefficients to evaluate the importance of different agromorphological traits in wheat and concluded that correlation and path coefficients were found to be different between wheat varieties. On the basis of path coefficient analysis, the direct and indirect contribution of spikelets spike ${ }^{-1}$; grains spike $^{-1}$ and seed index were maximum on seed yield. The above findings revealed that, whatever the character chosen for increasing the seed yield, the improvement could be achieved only through these traits. All the above characters exhibited indirect effect through spikelets spike $^{-1}$; grains spike ${ }^{-1}$ and seed index. Hence, it may be concluded that these are the main trait which are responsible for the manipulation of seed yield in wheat. Selection for any other yield contributing character will reflect on seed yield only through these traits.

\section{References}

1. Gupta PK, Kulwal PL, Rustgi SB (2005) Wheat cytogenetics in genomic era and its relevance to breeding. Cytoget Genome Res 109: 250-258.

2. GOP (2013) Area and Production of Other Major Kharif and Rabi Crops. Economic Survey of Pakistan (2012-13), Ministry of Food and Agriculture; Federal Bureau of Statistics, Government of Pakistan, Islamabad, pp.22.

3. Ali Y, Atta MB, Akhter J, Monneveux P, Lateef $Z$ (2008) Genetic variability, association and diversity studies in wheat (Triticum aestivum L.) germplasm. Pak J Bot 40: 2087-2097.

4. Hussain T, Muhammad AT, Zahid A, Javed I, Rehman A, Rabbani G (2014) Estimation of some genetic parameters and inter-relationship of grain yield and yield related attributes in certain exotic lines of wheat (Triticum aestivum L.). Journal of Biology, Agriculture and Healthcare 4(2): 48-53.
5. Hannachi AR., Fellahi ZA, Bouzerzour H, Boutekrabt A (2013) Correlation, path analysis and stepwise Regression in Durum Wheat (Triticum Durum Desf.) under rainfed conditions. Journal of Agric and Sustainability 2: 122-131.

6. Fellahi Z, Hannachi A, Bouzerzour H, Boutekrabt A (2013) Correlation between traits and path analysis coefficient for grain yield and other quantitative traits in bread wheat under semi arid conditions. J Agri and Sustainability 3(1): 16-26.

7. Sokoto MB, Abubakar IU, Dikko AU (2012) Correlation Analysis of some Growth, Yield, Yield Components and Grain Quality of Wheat (Triticum aestivum L.). Nigerian Journal of Basic and Applied Science 20(4): 349-356.

8. Shahryari R, Eshgh AG, Mollasadeghi V, Serajamani R (2013) Separating correlation coefficients into direct and indirect effects of important morphological traits on grain yield in 28 bread wheat genotypes under terminal drought stress. Int J Farming and Allied Sci 2(24): 1210-1216.

9. Dokuyucu T, Akkaya A, Akcura M (2002) Path analysis of yield and some yield related traits of Durum wheat genotypes grown in rainfed conditions of Mediterranean Region. Turk J Field Crops 7 (1): 31-39.

10. Turk M, Celik N (2006) Correlation and path coefficient analyses of seed yield components in the Sainfoin (Onobrychis sativa L.). J Biol Sci 6(4): 758-762.

11. Dewey DR, Lu KH (1959) A correlation and path coefficient analysis of components of crested wheat grass seed production. Agronomy Journal 51: 515-518.

12. Aydin N, Ermet C, Mut Z, Bayramolu HO, Ozcan H (2010) Path analyses of yield and some agronomic and quality traits of bread wheat (Triticum 
aestivumL.) under different environments. Afri J Biot 9 (32): 5131-5134.

13. Gelalcha S, Hanchinal RR (2013) Correlation and path analysis in yield and yield components in spring bread wheat (Triticum aestivum L.) genotypes under irrigated condition in Southern India. African J Agri Res 8(24): 3186-3192.

14. Rao VT, Mohan YC, Bhadru D, Bharathi D, Venkanna V (2014) Genetic variability and association analysis in rice. Int J of App Bio and Pharma Tech 5(2): 63-65.

15. Kumar GP, Prashanth Y, Narsimha VR, Kumar SS, Rao V (2014) Character association and path coefficient analysis in maize (Zea mays L.). Int $J$ of App Bio and Pharma Tech 5(1) 257-260.

16. Pujer SK, Siwach SS, Sangwan RS,

Sangwan O, Deshmukh J (2014) correlation and path coefficient analysis for yield and fibre quality traits in upland cotton (Gossypium hirsutum L.). J Cotton Res Dev 28(2): 214-216.

17. S, Nouri F, Sasani S, Nazafian G, Aghayari F (2013) Correlation and path analysis of grain yield and its components of some bread wheat (Triticum aestivem L.) under normal and source restriction conditions. Int J Farming and Allied Sci 2(23): 10651069.

18. Mollasadeghi V, Imani AA, Shahryari R, Khayatnezhad M (2011) Correlation and Path Analysis of Morphological Traits in Different Wheat Genotypes under End Drought Stress Condition. Middle-East J Sci Res 7 (2): 221-224.

19. Josm BK (2005) Correlation, regression and path coefficient analyses for some yield components in common and Tartary buckwheat in Nepal. Fagopyrum 22: 77-82. 